\title{
Nigeria's upstream petroleum industry anti-corruption legal framework: the necessity for overhauling and enrichment
}

Nigeria's upstream petroleum industry

\author{
Olusola Joshua Olujobi \\ Department of Public and International Law, Faculty of Law, \\ Elizade University, Ilara-Mokin, Ondo State, Nigeria
}

\begin{abstract}
Purpose - This study aims to investigate why anti-corruption statutes are not efficient in Nigeria's upstream petroleum industry.

Design/methodology/approach - This study is a doctrinal legal research that embraces a point-bypoint comparative methodology with a library research technique.

Findings - This study reveals that corruption strives on feeble implementation of anti-corruption legal regime and the absence of political will in offering efficient regulatory intervention. Finally, this study finds that anti-corruption organisations in Nigeria are not efficient due to non-existence of the Federal Government's political will to fight corruption, insufficient funds and absence of stringent implementation of the anti-corruption legal regime in the country.

Research limitations/implications - Investigations reveal during this study that Nigerian National Petroleum Corporation (NNPC) operations are characterised with poor record-keeping, lack of accountability as well as secrecy in the award of oil contracts, oil licence, leases and other financial transactions due to nondisclosure or confidentiality clauses contained in most of these contracts. Also, an arbitration proceeding limit access to their records and some of these agreements under contentions. This has also limited the success of this research work and generalising its findings.

Practical implications - This study recommends, among other reforms, soft law technique and stringent execution of anti-corruption statutes. This study also recommends increment in financial appropriation to Nigeria's anti-corruption institutions, taking into consideration the finding that a meagre budget is a drawback.
\end{abstract}

Social implications - This study reveals that corruption strives on feeble implementation of anticorruption legal regime and the absence of political will in offering efficient regulatory intervention. Corruption flourishes due to poor enforcement of anti-corruption laws and the absence of political will in offering efficient regulatory intervention by the government.

Originality/value - The study advocates the need for enhancement of anti-corruption agencies' budgets taking into consideration the finding that meagres budgets are challenge of the agencies.

Keywords Corruption, Transparency, Soft law approach, Upstream petroleum industry

Paper type Research paper

(C) Olusola Joshua Olujobi. Published by Emerald Publishing Limited. This article is published under the Creative Commons Attribution (CC BY 4.0) licence. Anyone may reproduce, distribute, translate and create derivative works of this article (for both commercial and non-commercial purposes), subject to full attribution to the original publication and authors. The full terms of this licence may be seen at http://creativecommons.org/licences/by/4.0/legalcode

The financial contribution of Covenant University, Nigeria, is greatly appreciated.
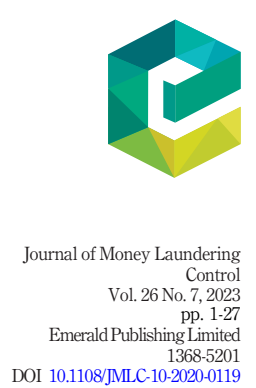
JMLC

26,7

\section{Introduction}

Crude oil is the central fount of Nigeria's economy is beset with an inherent and pervasive problem of corruption. This has hampered the economic development of Nigeria. Despite the current global development concerning the usage of alternate energy and the need to downplay on crude oil, the government delve into numerous alternatives to efficiently solve this challenge through anti-corruption laws. It is anticipated that the Federal Government makes the best use of her oil revenues, while it lasts for significant growth in Nigeria by combating corruption from the oil industry.

Corruption is not particular to Nigeria; it is an international phenomenon. Corruption has significantly decreased the revenues of the Federal Government of Nigeria from oil. As a result, most Nigerians are living in penury, with the least human development index (World Bank, 2017). Nigeria is the eighth leading producer of crude oil globally and is the fifthlargest in the Organization of Petroleum Exporting Member States (Omorogbe, 1996). Corruption and misappropriation of crude oil revenues have been made worst by the international deterioration of crude oil prices. The declining effect the request for Nigeria's crude oil on the global market is causing total operational expenditures owing to archaic and derelict petroleum substructure or assets in the industry.

Besides, corruption in Nigeria's upstream petroleum industry is also beset with several other challenges: pipeline damage and crude oil theft by insurgents in the Niger Delta areas, triggering the petroleum production to drop from 2.3million barrels per day to one million barrels per day (bpd) at the inception of 2016 (Olujobi and Olujobi, 2020).

This drop-in crude oil production has occasioned the incorporation of force majeure [1]; the section in petroleum contracts by energy firms in Nigeria. Corruption is predominant, notwithstanding the plethora of anti-corruption statutes and regulations in the country. Though, these are general anti-corruption statute not explicitly enacted for the upstream industry. Corruption continues to be the greatest challenge in the upstream petroleum industry.

Consequently, most eminent researchers from different fields have done several scholarly works on corruption, its indicators and how to fight (Abdullahi and Madu, 2015). However, it seems none of these workers has offered lasting panaceas to the problem occasioned by corruption in Nigeria's upstream industry. This existing study offers preferences for fighting corruption efficiently in the industry through the soft law method. This approach embraces, among other things matters, for instance, anti-corruption self-reporting tool, strict implementation and incentivisation of obedience to anti-corruption statutes.

Fighting corruption in the upstream petroleum industry is essential for the country's socio-economic growth and poverty obliteration. To be successful, the execution of these anti-corruption statutes must be done with genuine dedication supported by sturdy political will. The government is offering efficient statutory intervention by offering the required support to anti-corruption agencies. It will also necessitate the sensitisation of citizens on the harmful effects of corruption in the industry.

Corruption in the oil industry is not a new conception. Several such instances have been recorded. For instance, the sum of $\$ 12.2 \mathrm{bn}$ suspected to have been misappropriated during the oil windfalls in 1991. This was revealed by the Pius Okigbo Panel during General Ibrahim Babangida's regime. The alleged sum is yet to be reclaimed (Okojie and Momoh, 2005). The amount could have been used on infrastructural improvement in Nigeria. Also, in 1998 and 1999, Chevron Nigeria Limited was indicted for tax circumvention and deception (Otusanya, 2011a, 2011b). The firm was suspected of having eluded approximately US $\$ 2.7 \mathrm{bn}$ tax in addition to the accrued fines of $\$ 8,100,000$ (Anele, 2015). In collusion with some tax officials, the purpose was to reprocess the sum of tax owed to the Federal Government 
by $\$ 76 \mathrm{~m}$, (Otusanya, 2011a, 2011b). Thus, divesting the government of its legal revenues for growth-related tasks in Nigeria. This fraud was ascribed to the feeble execution of its anticorruption and legal transparency regime in the sector (Figure 1).

Transparency in the petroleum industry will be enriched Transparency International Corruption Perception Index yearly ranking of Nigeria, encouraging evolution, effectiveness, accountability and comprehensive statutory framework and healthy rivalry in the industry.

\section{Methodology}

This study is a library-based doctrinal legal research. It is buttressed by a contextual legal assessment, comprising a reference to internet sources, a comprehensive appraisal of academic literature, assessment of case studies and evaluation of pertinent judicial and statutory provisions. The assessment x-rays the weaknesses in Nigeria's anti-corruption statutes. The objective is to transform Nigeria's upstream petroleum industry anticorruption statutes.

This study uses periodicals, textbooks and internet sources as secondary sources. Primary sources, for instance, case laws, judicial precedent, significant international anticorruption conventions for attaining valuable insight to recommend the transformation of Nigeria's anti-corruption legislation to enhance transparency and accountability in the industry.

\section{Statement of research problem}

The perceptions of legal researchers have been attracted to the feeble regulatory governance in Nigeria's petroleum industry. The weak legal regime has a damaging consequence on the economic growth of Nigeria (Take, 2014). Corruption upsurge operation expenditures in the industry, thus damaging the sensible and appropriate administration of energy resources for the growth of Nigeria.

In 2011, the Royal Dutch Shell petroleum company and Eni were suspected of having fleeced the Federal Government by $\$ 1.1 \mathrm{bn}$. The two firms did this by awarding oil block OPL 245 to Malabu Oil and Gas Limited (Carvalho, 2017). The firm was purportedly held by the erstwhile Nigerian Petroleum Minister, Dan Etete. Mr Etete, who granted the oil block to the firm while in office in violation of Corporate Governance's Code and Code of Conduct Bureau and Tribunal Act [2] as stated under the Fifth Schedule of the 1999 Constitution of the Federal Republic of Nigeria (as amended). An exciting twist to the Malabu corruption

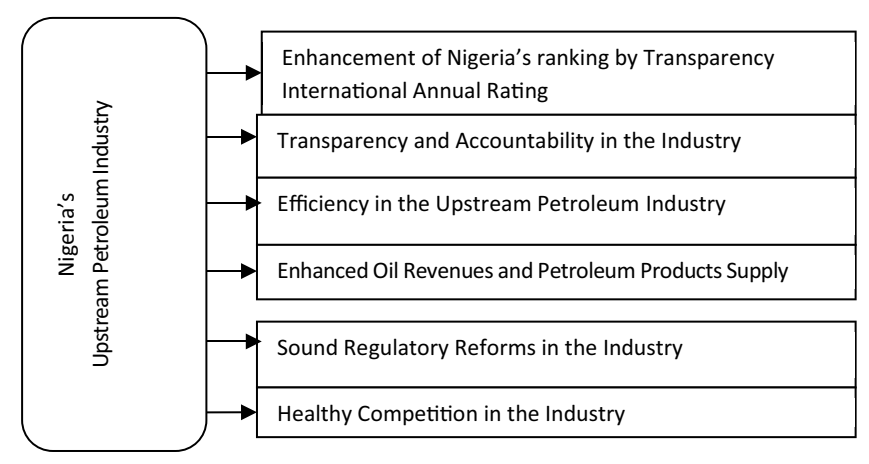

Source: The Author prepared this

Figure 1. Advantage of transparent petroleum industry 
JMLC 26,7

saga is the fact that those who were accused of bribery overseas in regard of this contract have been sentenced, while those accused in Nigeria have neither been charged nor arraigned. This owing to the feeble execution procedures in the anti-corruption statutes (Global Witness, 2017). However, later, the UK's court struck out the $\$ 1.1$ bn Nigerian corruption charge against Shell, and Eni for lack of jurisdiction in regard of the disagreement over the award of OPL 245 oil field amount made as an inducement to acquire the grant, but the firms are standing prosecution in an Italian court (Olisah, 2020).

The 2012 report of the Petroleum Revenue Special Task Force also uncovered an additional form of corruption to the extent that oil block tenders from 2005 to 2007 were portrayed by corruption and compulsory amalgamations. It was also revealed in the report that partisan preferences were granted to specific oil firms devoid of their practical knowledge or economic proficiency of the award (Ribadu, 2012). This task force was inaugurated by the former Minister for Energy Resources, Diezani Allison Madueke, on behalf of the Federal Government and was chaired by Mallam Nuhu Ribadu. The report further uncovered that seven discretionary licences value at over $\$ 183 \mathrm{~m}$ in signature bonuses were not remitted to the Federation Account from 2005 to 2011. These gaps were due to the faulty execution of the Petroleum Profits Tax Act by the Federal Inland Revenue Service, which has triggered the forfeiture of oil revenues to the Federal Government.

There appears to be a severe challenge in the management of signature bonus in Nigeria. For instance, there was over US\$566m in outstanding signature bonuses and statutory payments that some oil firms ought to have disbursed ahead of one's time to the Federation Account. Opaque modus operandi of handling signature bonuses and inadequate documentation systems in the Department of Petroleum Resources were also uncovered. The Petroleum Profit Tax fees made by the oil firms were entrenched on unsubstantiated self-evaluation. This was acknowledged devoid of additional validation by the Federal Inland Revenue Service, which also triggered the forfeiture of oil revenues due to the Federal Government owing to feeble execution of its anti-corruption legal regime (Ribadu, 2012). The submissions of the Committee for the incorporation of transparency in its operations have not been implemented.

Equally, there is the Halliburton bribery infamy, where the sum of US\$180,000,000.00m was purportedly presented as a bribe to procure the contract for developing of the Bonny Island Liquefied Natural Gas scheme between 1995 and 2004 (Barbara and Kathleen, 2006). Halliburton's subsidiary Kellogg, Brown and Root was accused of the infringements of Foreign Corrupt Practices Act. The United States' Government penalised Halliburton $\$ 579 \mathrm{~m}$, and its chief executive officer was sentenced to seven years' incarceration (Ajuzie, 2010).

Corruption has continuously been a problem in the upstream industry, predominantly in the NNPC. The Federal Government has made some regulatory and legal attempts to enhance transparency in the industry by inaugurating the Nigeria Extractive Industry Transparency Initiative [3]. Moreover, the Sovereign Wealth Funds to administer extra income from crude oil [4]. The Niger Delta Development Commission (NDDC) [5] was also inaugurated to promote rapid and sustainable development of the Niger Delta oil-producing areas. The Federal Government also introduced the Amnesty Programme to sustain harmony and growth in the Niger Delta Area through the provision of occupational skills and training of rehabilitated revolutionaries. The Federal Government also inaugurated the Presidential Advisory Committee against Corruption (PACAC) in August 2015 (The Presidency, 2016). The Presidential Committee on Assets Recovery to recover stolen wealth and assets on 18 November 2016, and the National Prosecution Coordination Committee to advice on corruption cases 27 May 2016 [6]. However, the Committee was later dissolved. 
The government also annulled the Infrastructure Protection Contracts with the former revolutionaries owing to the predominance of crude oil theft and corruption in the oil industry. The recent forensic audit of the NDDC by the House of Representative uncovered misappropriation of $40 \mathrm{bn}$ by its Interim Management Board. It is the Constitutional obligation of the lawmakers to ensure, entrench, uphold transparency, accountability, swift and viable social and economic growth of the region by enacting stringent anti-corruption laws (Ayado, 2020).

Conversely, as international interest is changing from fossil fuels to renewable energy, there is rejuvenated uproar among Nigerians for the diversification of the economy. This has been mainly due to the international oil price crash, little request for Nigeria's crude oil on the global market, and the prevalent corruption in the oil industry. Oil costs have plunged extensively from $\$ 110$ a barrel in 2010 to $\$ 48$ per barrel in 2014 and $\$ 31$ per barrel in 2016 (Bello, 2017) but augmented to $\$ 54.15$ per barrel in 2017, $\$ 72.8$ in 2018 and $\$ 65.06$ in 2019 (Nigerian National Petroleum Corporation (NNPC), 2020) Moreover, currently, in August 2020, $\$ 45.08$ a barrel (organisation of the Petroleum Exporting Countries, 2020). This has declined the revenues of the Federal Government from crude oil in Nigeria.

These occurrences prompted various anti-corruption probes, such as the reports of the Nigeria Extractive Industries Transparency Initiative (NEITI) 1999-2004, 2005, 2006-2008. The reports of the audit of the importation of fuel commission by the NNPC in 2008 and 2009-2011 with the report of the audit of the NNPC by KPMG Professional Services submitted to the Presidency on 22 November 2010, which exposed corruption in the sector. The 2012 Report of the Mallam Nuhu Ribadu Petroleum Revenue Special Task Force set up by the Federal Government too uncovered different corrupt practices in the sector.

The above-mentioned anti-corruption audit reports brought to the fore lack of transparency, which promotes corruption and retards development in the sector. These occurred due to the absence of political will on behalf of the Federal Government to combat corruption. These corruption cases have been perennial features of the sector. Therefore, there is a need for a proactive approach to combat corruption in the oil sector. Transparency in the sector is critical to national development since the sector accounts for more than $95 \%$ of Nigeria's foreign exchange earnings.

Because of large-scale corruption in the sector, many international oil companies are now divesting their interests, and this has also resulted in extensive poverty and infrastructural deficit in Nigeria, despite being endowed with abundant petroleum resources. According to Reuters (2004), Nigeria is said to have lost up to $40 \%$ of its oil revenues to corruption. However, international anti-corruption conventions and national anti-corruption laws have been enacted to combat corruption in the sector.

\section{Literature review}

One of the problems that give room for corruption in the oil industry is the dearth of a political will to fight corruption by the Federal Government. This gap has occasioned opaque and absence of good governance, notwithstanding the numerous anti-corruption investigation reports that have exposed corruption in the industry. The absence of steadfastness to fight malfeasance and other corrupt practices has occasioned disinclination of specific transnational anti-corruption organisations from offering their maximum assistance on repatriation of proceeds of corruption to Nigeria. These anti-corruption investigation reports have not been used to acquire valuable insights to reform the industry. Meanwhile, individual government representatives are purportedly profiting from fraudulent practices, thus defying and sabotaging all transparency mechanisms. This has caused the loss of oil revenues to the Federal Government from the industry. 
JMLC 26,7

The ultimate conundrums with the anti-corruption legal framework are weak execution and the equivocality of the laws. Equivocal laws make it problematic to comprehend its aims, occasioned loss of corruption lawsuits in a court of law [7]. This is apparent in Section 404(1)(a) of the Criminal Code that prescribes the demand for property. Equally, the plethora of anti-corruption legislation fails to combat corruption in both the private and public sectors simultaneously. Many of the upstream petroleum firms are private firms, thus dwindle the execution of anti-corruption laws and emboldening corrupt practices in the industry.

Meanwhile, the legislation relating to bribes of public officials shows the offering, promising, giving and acknowledgement of bribes. Though, the implementation of the legislation is ineffectual. Feeble implementations of anti-corruption legislation by anticorruption organisations due to corruption and bribery have caused the loss of oil revenues to the government. Such oil revenues could have been used for infrastructural enhancement in the country if there was conformity with the anti-corruption legislation. There would also be constant supervision and assessment of compliance by the anti-corruption organisations, upstream petroleum regulatory body and other participants in the industry.

As a result, in 2004, Nigeria instituted an investigation panel to probe the claim of corruption in the industry but the former Attorney General of the Federation (AGF) and Minister of Justice Mr Michael Aondoaaka used little administrative reprieve rather than criminal prosecution of Halliburton suspects (Igbinedion, 2011). This was an infringement of the basis for Sections 174(1)(c) and 211 of the 1999 Constitution (as amended) that authorised the AGF to initiate, withdraw and continue criminal trials against any person before any court of law in Nigeria with conditions of considering public concerns, fairness and due process before the use of such authorities. This misuse of the power of nolle prosequi by the former AGF triggered the forfeiture of oil revenues by the Federal Government through recurrent unprosecuted pervasiveness of corruption in the oil industry.

The inelegant prosecution of corruption lawsuits exhibits that the Federal Government lacks the political will to fight corruption in the industry. As nobody has been fruitfully arraigned for the Halliburton corruption incident in Nigeria, while the other perpetrators have been sentenced in the USA and Germany, this has caused mockery to the nation on the global outlook. The deterioration in oil revenues and financings in the industry as it appears that the government has determined not to arraign the recipients of Halliburton bribery incidents (Ogbonna-Nwaogu, 2010). A strong political will is a prerequisite for the efficient implementation of anti-corruption legislation to promote transparency and accountability in the oil industry in Nigeria.

Without doubt, Nigeria's mono economic position and over-reliance on crude oil for national revenues (Nwanolue and Osegbue, 2013). Have caused the industry to be susceptible to corrupt practices and other oil-associated corruption, thus occasioned oil price instability and deteriorated oil revenues. This seems to be a risk to the global energy resource market due to challenges of development and growth triggered by the predominance of corruption in the industry. The country's economy has been volatile owing to rising hostility in the industry. The desertion of other non-oil sectors, for instance, agriculture and solid minerals and others that would have made engendered more revenues for the Federal Government of Nigeria are a flaw to the country.

Also, the absence of transparent and distinct metering apparatus for quantifying crude oil transactions or churn out which has created opportunities for corruption, malfeasance and loss of oil revenues by the government for socio-economic growth in Nigeria is a drawback. NNPC's reports on crude oil engendered and traded are full of inconsistencies owing to clandestineness in their undertakings. Likewise, the dearth of strict legal regime on 
updated record preservation and non-existence of legal provisions in the Act for prompt publication of its comprehensive financial reports to the public. This has encumbered transparency and emboldened predominance of corruption in the upstream oil industry's revenues.

Furthermore, the NEITI audit report showed that the new Port Harcourt refinery does not have the metering paraphernalia for computing the crude oil transmission via pipelines to depots throughout 1999-2004 owing to non-existence of law on obligatory and translucent use of metering apparatus for computing crude oil transactions or engender. This offered opportunity for dishonesty, the dearth of accountability and loss of oil income by the government from the industry (Nwokeji, 2007). The suspected missing US $\$ 20 \mathrm{bn}$ oil revenues from the NNPC as claimed by the former Governor of the Central Bank of Nigeria, Lamido Sanusi, through domestic crude oil transactions remains unresolved (Akinola, 2015) owing to weak enforcement of transparency laws. The flaw of regulatory and anticorruption agencies in the sector triggered a decline in national oil revenues for modernisation schemes in the country.

Further, the 2009 and 2011 NEITI's reports uncovered that certain oil and gas firms connived with individual tax executives to evade tax overheads of about $\$ 8.3 \mathrm{bn}$. The sums that they ought to have credited to the Federal Government's account (Nigeria Extractive Industry Transparency Initiative, 2014). However, owing to the weak application of the provisions of the Petroleum Profits Tax Act, all of these have created opportunities for corruption and decline oil revenues deposited on the Federal Government.

Similarly, the task of restructuring in NNPC due to corruption and ongoing shortage of oil revenues as the present structure of the Corporation negates global standards and procedures for the sustainable, translucent viable legal entity, which is autonomous with the self-accounting system on revenues. This will ensure transparency comparable to Statoil in Norway, which functions like other profit-making oil firms devoid of any distinct status of a statutory conglomerate, where the governments only act as a supervisory body and charge corporate taxes; this has improved transparency in their upstream petroleum industry. Overhauling of Nigerian National Petroleum Corporation Act [8] to obliterate the Minister of Petroleum and Energy Resources as the chairperson of the NNPC's board will boost transparency through check and balance and comprehensive scrutinisation of NNPC's oil transactions in the industry. Section 7 of the Act provides that the Corporation shall keep appropriate books and accurate records concerning it a procedure, which shall correspond to the best business-related standards. The Corporation has not been keeping appropriate registers and books that can boost transparency and accountability in all its contracts in the industry. All its business undertakings and processes are embodied with opaqueness and clandestine. Section 7(4)(a)(b) of the Act infringes Section 162 of the 1999 Constitution by permitting the Corporation to retain funds to finance its undertakings. The Corporation has relied on the misperception established by Section 7 of the Act to maintain a certain sum out of the standard public financial management controls. The author opined that there is a necessity to enact an apt law on how the NNPC should fund its businesses or undertakings and maintain appropriate registers of its dealings. Tolerating NNPC's businesses to be done in clandestineness will encourage corruption and inefficiency, and it would cost Nigeria colossal loss predominantly at this period of international deterioration in oil values. Alteration of the Act is desirable to explain in simple terms how NNPC's in-house cost control mechanisms should be boosted through regular audit and appropriate maintenance of accounting records of all transactions in the industry. The Act if executed professionally, should fight corruption and entrenched transparency in the industry after the lacunae pinpointed have been remedied. 
JMLC 26,7

Besides, there were over US\$566m unpaid signature bonuses and regulatory fees that some upstream petroleum firms ought to have paid beforehand to the Federation Account. This sum triggered deficit in oil revenues of the government. Opaque systems of managing signature bonuses and inelegant record-keeping practices in the Department of Petroleum Resources were also revealed by Nuhu Ribadu's report in 2012. The Petroleum Profit Tax tariffs made by individual petroleum firms were based on unsubstantiated self-assessments. These fees were acknowledged devoid of further confirmation by the Federal Internal Revenue Service to enhance transparency in the industry. The suggestions of Nuhu Ribadu's Committee to strengthen transparency in the activities of the industry have not been implemented to combat corruption in the industry.

Furthermore, in 2013, the audit report of the NEITI claimed that NNPC has not transmitted dividends aggregating to $\$ 14.34 \mathrm{bn}$ of the Nigeria Liquefied Natural Gas (NLNG) Project with an interest and credit reimbursement to the total of $\$ 12.92 \mathrm{bn}$ to the Federation Account (Nigeria Extractive Industries Transparency Initiative (NEITI), 2013). This is due to the non-existence of legislation, obliging it to transmit the money directly to the Federation Account. Besides, this has created an opportunity for corruption and shortfall in oil revenues accumulating to the Federal Government for improving the country's infrastructures.

The non-disbursement of oil remunerations by NNPC and some of its firms to the Federation Account that could have been spent on infrastructural improvement in the country. However, owing to the shortcomings in Sections 80, 162(1) of the 1999 Constitution (as amended), which neglected to specify the time frame explicitly for the payment of oil revenues to the Federation Account. Refusal to curtail discretionary expenditure by NNPC, which has created an opportunity for corruption in the industry.

The lack of transparent financing model legislation and the variance between the country's Constitution and Section 7 of the NNPC Act on oil revenues expenditure thus opening the opportunity for corruption in the Corporation by withholding oil revenues accruing to the Federal Government as operational costs in the sector.

For instance, in 2014, the report of the NEITI audit on oil and gas industries revealed non-remittance of oil revenues of over N2.23tn by the NNPC to the Federation Account (Nigeria Extractive Industries Transparency Initiative, 2014). This was a flagrant infringement of the Constitution and Fiscal Responsibility Act, 2007. NEITI's 2015 audits and reports uncovered the refusal of NNPC, Nigerian Petroleum Development Company (NPDC) and other oil firms to pay the aggregate of N3.78bn to the Federation Account (Nigeria Extractive Industries Transparency Initiative Policy Brief, 2017). NEIL's Annual Progress Report, 2016, also uncovered that unremitted dividends of the NLNG project worth $\$ 15.823 \mathrm{bn}$ on loans and interests from the year 2000 to the year 2014 were paid to NNPC but were not paid to the Federation Account (Nigeria Extractive Industries Transparency Initiative (NEITI), 2016), thus, providing the opportunity for corruption and deficit in oil revenues accumulating to the government from the industry.

Further, in 2014, the assessment report of the NEITI on oil and gas industries uncovered non-remittance of oil revenues aggregate N2.23tn by the NNPC to the Federation Account (Nigeria Extractive Industries Transparency Initiative, 2014). Also, the laws regulating Nigeria's upstream petroleum industry are outdated. They do not signify the existing legal improvements and foreseen legal impediments in the industry. NEITI uncovered that the Federal Government lost the aggregate of N1.74tn in oil revenues in 2013 due to non-passage of Petroleum Industry and Governance Bill (PIGB) and other essential petroleum laws to transform the industry (Moghalu, 2018). There is then the need for a complete amendment of the laws to fight corruption and to embolden transparency in the industry. 
Moreover, the forensic audit report performed by Price Waterhouse Coopers for the Federal Government on businesses or undertakings of the NNPC on the non-payment of crude oil revenues in 2012 and 2013 has not been used. This would have offered some innovations to bridge the gaps pinpointed in our anti-corruption laws.

The report advocated, among others, reforms of the NNPC as the present arrangement of the Corporation negate viable lucrative legal entities in the industry. However, in the UK and USA, the governments only act as regulators and charge corporate taxes devoid of any national oil firms (Carlyle, 2020). This method enriches transparency in their oil industries different from Nigeria, where the NNPC executes both regulatory and commercial functions. Such roles open doors for corruption and misuse of discretionary authorities owing to the dearth of legislation that separates its regulatory and commercial tasks in the industry.

In the same way, the 2016 Nigeria Extractive Industry Transparency International's Annual Progress Report uncovered unremitted dividends (Onya and Elemanya, 2016) of the NLNG project worth US $\$ 15.823 \mathrm{bn}$ on credit and interests from 2000 to 2014 were paid to NNPC. The sums were also not paid to the Federation Account (Nigeria Extractive Industries Transparency Initiative [NEITI], 2016). This infringes on Sections 80, 162(1) of the 1999 Constitution (as amended) that state that all funds that are paid to the Federal Government must be remitted to the Federation Account thus aided corruption in the industry.

Corruption and misappropriation of oil revenues are alleged to be committed by the government's officials. These officials were alleged to have connived with conglomerate upstream petroleum firms, who are said to have given significant sums to government's executives in the industry to procure illicit oil contracts. This caused the loss of oil revenues to the government due to the absence of detailed due diligence mechanisms in the industry to evaluate oil contracts.

The Shell Petroleum Development Company, ChevronTexaco, ExxonMobil Corporation, Agip Oil Company and Total Oil Company are the leading oil firms in Nigeria. Some petroleum firms are suspected to be beneficiaries of corruption to the disadvantage of the Nigerian State and its populace. If this is not tackled, it may continuously impede economic development and transparency in Nigeria's petroleum industry (Nigeria Overview, 2015).

It is unarguable that, had the Federal Government fought corruption in the upstream industry and used the revenues prudently throughout the oil boom, the country would have registered exceptional infrastructural growth in all sectors. Though presently, oil prices have declined drastically from $\$ 110$ a barrel in 2010 to $\$ 48$ per barrel in 2014 and as little as $\$ 31$ per barrel in 2016 (Bello, 2017). In 2017 it was $\$ 44.5$ per barrel while in 2018 it was $\$ 57$ per barrel and in the first quarter of 2019, it was $\$ 63.17$ per barrel (Central Bank of Nigeria, 2019). Though, it is expected that Nigeria will expand its economy to other non-oil sectors such as agriculture and solid minerals to terminate its mono-economy position to stimulate economic steadiness and growth in Nigeria.

The NNPC, as the principal statutory Corporation regulating the industry, it may be considered indecipherable national oil corporation since its operations have been purportedly branded with corruption and clandestine. The system of awarding oil pioneer status to petroleum firms that have been thriving for years divests the government of its statutory oil revenues in the industry owing to the archaic legal regime governing Nigeria's petroleum industry, which opened to corruption.

Transparency in the income of the upstream petroleum industry is a necessity to eliminate corruption. Ayoade, in his work "Nigerian National Petroleum Corporation and Prospects for Transparency in the Petroleum Industry Bill," (Ayoade, 2011) promoted the necessity for transparency in the oil industry, as it has established that it is almost impossible to get precise 
JMLC

26,7

10

records on oil production in the country over the years, with the Central Bank of Nigeria, Ministry of Finance, Department of Petroleum Resources and international oil firms offering inconsistent statistics. Deficient statistics or records accessibility and non-record-keeping culture are features of persistent corruption in the industry. It is the writer's opinion that the article botched to highlight the implementation of the recommended penalties. Currently, the Bill has been overtaken by the Petroleum Industry Governance and Institutional Framework Bill, 2017, which is still pending at the National Assembly.

Also, in underlining the dearth of transparency in the industry, Oyewunmi and Olujobi in their article "Transparency in Nigeria's Oil and Gas Industry: Is Policy Re-Engineering the Way Out?," (Oyewunmi and Olujobi, 2016a, 2016b) argued that clandestineness in the method of awards of petroleum contracts, licences, leases and other transactions in the industry by the NNPC is due to the lack of provisions in the NNPC Act [9] on transparency and record-keeping. It is the author's perspective that public announcement of financial transactions or operations of NNPC and National Petroleum Investment Management Services should not contravene business contracts' confidentiality clauses in the industry. It is opined that transparency legislation should incorporate voluntary reporting techniques to discourage corruption, but the paper being deliberated also failed to discuss the implementation problems of anti-corruption laws.

Furthermore, Eigen, in his work "Fighting Corruption in a Global Economy: Transparency Initiative in the Oil and Gas Industry," (Eigen, 2007) summarised the extractive industry transparency initiatives purpose to stimulate transparency by demanding firms to divulge all revenues disbursed to the government besides the declaration of revenues collected by the government from extractive businesses, with an independent auditor endorsing the correctness of the amounts disclosed for public scrutinisation of how oil revenues are expended. He neglected to concede how the dearth of stringent penalties for non-conformity with its provisions affects the efficiency of the agency.

Also, the lacunae in the literature that this study intends to fill are the absence of several specific anti-corruption legislation in Nigeria's anti-corruption legal regime. For instance, incentivised Whistle-blowers Protection Act and Civil Forfeiture of Proceeds of Corruption Act, absence of legal templates or frameworks for the domestication of international anticorruption conventions in the industry and the rebuttal to incorporate and implement stringent enforcement of both the hard and soft law methods in fighting corruption in the industry in coincidence with international assistance hindered the efficiency of the current national anti-corruption laws in Nigeria's upstream petroleum industry as proposed by this paper. Though, Section 5 of the Act positioned the duty of employing National Stakeholders Working Group members on the President devoid of any legislative authorisation by the National Assembly. This is a fundamental flaw of the Act. This requires modification to enhance transparency in the industry. Also, in his article "A Critique of the Enforcement of Nigeria Extractive Industries Transparency Initiative (NEITI) Act 2007 in Nigerian Oil and Gas Sector," (Okeke, 2013) Okeke debates that Section 16 of the Act stipulated the penalty of N5-30m or incarceration for two years as tentative sanctions for oil firms, their directors and government's officials who present false data or neglect to offer any evidence when necessary. The punishments seem to be inadequate, seeing the billions of dollars that are engendered from the industry. Two years of incarceration do not have stringent deterrence value, seeing the prevalence of corruption in the industry.

\section{Theoretical framework on corruption in Nigeria's upstream petroleum industry}

A plethora of theories has been explained by legal researchers accentuating the basis of corruption and how it can be tackled. An appreciation of these theories can give acumen into 
these conundrums and, in the context of this research, can aid in tackling corruption predominant in Nigeria's upstream petroleum industry.

This study seeks the execution of the current anti-corruption legislation along with the amendment of the numerous drawbacks pinpointed in the process and the enactment of fundamental anti-corruption legislation deficient in Nigeria's anti-corruption legal regime. Three fundamental theories indispensable to this study are rent-seeking theory of corruption, extractive theory of corruption and public choice theory of corruption. They are painstaking valuable in the evaluation of the study.

\subsection{Rent-seeking theory of corruption in the upstream petroleum industry}

Gordon Tullock described the doctrines of this theory in 1967. Though, the theory has been drawn from the study of Anne Krueger (1974) and (Henderson, 2020). The model assists the study by describing the rent-seeking theory of corruption as the processes of disbursing resources that generate no social advantages to sway public policy outcomes, and accordingly, public resources expended are socially squandered. Concurring with the principles of this theory, rent-seeking is the distribution of resources and vitality in generating or transmitting rents (Mushtaq, 2000).

The rationalisation for the concept is that it lessens administrative rent-seeking undertakings and bottlenecks in Nigeria's upstream petroleum industry, and it encourages transparency and due processes in the industry. According to this model, corruption occurs in circumstances where artificial hurdles to entry are designed as channels for inducements or other detrimental conduct, for instance, lobbying. The theory centres on the cooperation between the state and other participants in the industry with the emphasis that the state has the authority to allocate exclusive rights on oil transactions through licencing, rules, taxes and by awarding oil transactions.

Nevertheless, the theory helps the research by arguing that artificial hurdles are designed by government officials in the industry through bureaucracy and administrative bottlenecks. Government officials, along with other participants in the industry sway the state to make these aid their egotism and manipulate oil firms in the industry. Corruption does not only arise in cases where oil firms offer inducements, so that artificial hurdles to entry are eliminated and so that they could function, but it also causes arguments over rent and triggers petroleum firms to contest for special attention, which contravenes due process.

Here, there is the necessity to distinguish between corruption and lobbying. Lobbying varies from corruption because it is legitimate, while corruption is illegal. Corruption is the financial benefit or other advantages transferred between a bribe-giver and a bribe-taker, while lobbying is a bid to sway another person devoid of any payments. In the same vein, corruption varies from other rent-seeking undertakings or actions owing to the diverging echelons of transparency.

The model recommends lessening of artificial hurdles by the state. The researcher of this paper (hereafter, the researcher) argues that specific hurdles to entry may be socially efficient; such as bureaucracy constituted to enter Nigeria's upstream petroleum industries by foisting the prerequisite of licence. This perceptible hurdle may thwart persons with fraudulent aims from securing access to the industry. The drawback of the theory is defining rules that caused artificial barriers and those that do not.

The theory also has flaws concerning the designing of incentives and management of moral conduct. To combat corruption in the industry, finding panaceas to these drawbacks are sine qua non. The researcher maintains that corruption impedes economic growth; thus, competitive lobbying is desirable to corruption. 
JMLC

26,7

\subsection{Extractive theory of corruption in the upstream petroleum industry}

Extractive theory of corruption is the affairs between state, its intermediary and the public. Here the states' agent uses the incomes of the state for the advantages of their leaders. The fact that the state is a sturdier party in the relationship that benefits most from corruption they are the prominent investors in the petroleum firms the state is perceived as a docile player. As quoted by Iyanda 1999, (Amundsen, 1999) Amundsen opines, (Iyanda, 2012) in his article "Corruption: Definitions, Theories and Concepts," that extractive theory is founded on the concept of authoritarianism - the usage of force and misuse of a State's income by leaders or their agents. Adebisi (2015) further exposed that the concept is centred on the notions of totalitarian government and neo-patrimonial States. Harmonising the anxieties concerning corruption, Amundsen (2020). In his work "Political Corruption: An Introduction to the Issues," maintains that some government officials benefit from corruption by using the state's mechanism to extort resources for the advantages of the ruling government.

The theory buttresses this work by deterring despotic rules and government's officials who use authorities and assets of the state (oil revenues) to safeguard their interests at the disadvantage of the country's economy and growth. The model emphasises a well-known hypothesis that power tends to pervert, and unlimited power causes absolute corruption. In other words, where extreme power is concerted entirely in the hands of a few individuals, for instance, the Minister of Petroleum and Energy Resources' discretionary power in the petroleum industry, give room for prospective corruption, misapplication of power, quest for wealth and extraction of wealth for the personal advantage.

\subsection{Public choice theory of corruption in the upstream petroleum industry}

This theory was advocated between 1950 and 1960. The leading advocates of the theory are James Buchanan, Gordon Tullock and Mancur Olson; Public Choice theory focuses on individuals' welfare and favourites which model ones' conduct in taking a coherent decision. This often turns out pre-determined objectives for such personalities through optimal usage of every value. The theory is often valuable for combating enhanced corruption. It permits one to envisage penalties of corruption as most anti-corruption laws are legislated with penalties for non-conformity.

The theory aids this study by underlining that individual is accountable for both his activities and penalties of his actions. In the petroleum industry perspective, the theory is bothered about corrupt government's officials who tried to use most of their utility in the industry through corruption. Graaf, in his article "Causes of Corruption: Towards a Contextual Theory of Corruption" argues that government's officials are sensible calculating personalities who only decide to become corrupt when the gains of corruption outweigh the demerits, which refers to the mixture of anticipated penalties and the possibility of being accused of corruption.

The theory elucidates the detrimental effects of corruption in the industry as follows: when one is corrupt, one is harming growth in the country. Langseth, in his work "Prevention: An Effective Tool to Reduce Corruption" opines that by making the sanctions stringent to discourage corruption in the sector, it is essential to connect the expenses of anticorruption organisations with the proceeds of corruption reclaimed from the industry. Anechiarico and Jacobs, 1996 in their article "The Pursuit of Absolute Integrity," argue that stricter punishments with severe precautionary measures may increase the probabilities of being apprehended for corruption and may upsurge the cost of corruption through comprehensive deterrent anti-corruption devices, which is centred on the uncompromised implementation of anti-corruption legislation and penalties in the industry. 


\section{International anti-corruption conventions in the upstream petroleum industry}

The United Nations Convention against Corruption [10] aim to thwart corrupt practices, illegal funds transfer, called money laundering, and private sector corruption, and to inaugurate a comprehensive monitoring regime for financial organisations to remove financial crimes. The researcher argues that the provisions of the convention can be used to retrieve proceeds of corruption for infrastructural growth in the country. Smith and Pieth, in their work "The Recovery of Stolen Assets: A Fundamental Principle of the United Nations Convention Against Corruption," (Smith and Pieth, 2007) underlined the significance of the treaty by avowing that it provides legal backing and technical aid to revert the proceeds of corruption.

Nliam, in his paper "Assessing the Adequacy of International and Regional Legal Framework Against Corruption in the Public Sector," (Nliam, 2015) claims that the United Nations Convention Against Corruption and the African Union Convention presents the legal backing for averting and tackling corruption through domestic anti-corruption legislation but neglects to tackle issues of asset confiscation and to emphasise the enactment of legislation governing sentence and non-sentence-based confiscation. The stipulations of the treaty on cross-border cash transfer of corruption proceeds specifically from the upstream industry have not been domesticated in Nigeria's anti-corruption legislation.

Similarly, member states are under the legal duty to inaugurate organisations to oversee assets seizure and to enact legislation to legalising prison term and non-sentence-based seizure. Nigeria has not initiated any agency to oversee asset confiscation and proceeds from corruption [11]. These tasks are currently undertaken by the various anti-corruption agencies devoid of accountability; transparency unified governing regulations on the management of such proceeds due to incessant allegations of misappropriation of such proceeds by the agencies.

Further, Nigeria has not enacted legislation governing non-sentence-based confiscation as stipulated under the convention; the Member States must integrate processes and procedure into their national laws to safeguard whistle-blowers in compliance with their laws (Organisation for Economic Cooperation and Development [OECD], 2011). This also has not been effected in Nigeria. The Whistle Blowers Protection Policy in existence; it is not law and cannot be adequate to protect the exposures of whistle-blowers or eyewitnesses who appear in a court of law to testify against corrupt government's executives. In the case of the Federal Military Government v. Sani [1990] 7 SC (Pt. II) 893909 the court held that a policy of any government that has not been legislated into law could not stand as a basis for the punitive measure. This lacuna has been indicated as a severe deficiency to anti-corruption undertakings in the industry.

Guzman (2020), writing on "Compliance Based Theory of International Law,” opines that the fundamental drawback in the convention is the non-existence of legal measures to reprimand erring States members' for non-observance of the terms of the convention. Lucinda asserts that failure to criticise the usage of discretionary terminologies in the convention devoid of any mandatory terms seems the convention is "a toothless legal instrument" (Lucinda, 2020).

It is the analysis of the researcher that weaknesses in the convention, failure to outlaw non-cash forms of bribery, for instance, allotment of shares, hospitality tickets and failure to declare illegal funding of alien political parties, in the convention should be modified. Confirming the impacts of the convention, Davis (2020), in his work "Does the Globalisation of Anti-Corruption Law Help Developing Countries?" advocates that despite these weaknesses, the convention has recorded significant inputs in the global anti-corruption

\section{Nigeria's \\ upstream \\ petroleum industry}


JMLC

26,7

fight. The researcher opines that implementation has been a significant flaw of the convention in fighting corruption.

Substantiating the successes of the convention, Padideh studied the case of Mabey and Johnson who were reprimanded for offering bribes to government's officials in Ghana, Angola, Madagascar and Jamaica to obtain business gains as commendable in "Controlling Corruption in International Business: The International Legal Framework" (Padideh, 2020). The researcher thinks that implementation has been the main drawback of the convention, which the article did not comprehensively examine.

Even though Nigeria's government assented to some of these conventions, they are yet obligatory owing to Section 12 of the 1999 Constitution (as amended), which requires the National Assembly to domesticate convention or treaties by legislating on it as national laws. The researcher submits that numerous lacunae in the conventions should be modified for efficiency in combating corruption in the upstream petroleum industry.

\section{Corruption in Nigeria's upstream petroleum industry}

Transparency in the income of the upstream petroleum industry is the prerequisite to exterminate corruption. Ayoade, in his article "Nigerian National Petroleum Corporation and Prospects for Transparency in the Petroleum Industry Bill," (Ayoade, 2011) promoted the necessity for transparency in the petroleum industry, as it has been established to be challenging to obtain precise statistics on oil production in Nigeria in recent years, with the Central Bank of Nigeria, Ministry of Finance, Department of Petroleum Resources and multinational oil firms offering inconsistent data. Poor information accessibility, poor documentation and preservation culture are features of prevalent corruption in the industry. It is the researcher's perspective that the article neglected to accentuate on the weak implementation of the specified sanctions. Currently, the Bill has been exceeded by the proposed Petroleum Industry Governance and Institutional Framework Bill, 2017, which is currently pending at the 9th National Assembly for review and possible assent by the President.

As part of the evaluation on transparency, Nweke, in his article "Corporate Social Responsibility and Transparency in the Development of Energy and Mining Projects in Emerging Markets: Is Soft Law the Answer?" (Nweke, 2017) opined that the tactic of the government to transparency has been on the issue of hard laws and recommended the usage of soft laws and voluntary reportage instrument as substitute governing measures to inspire oil firms to offer data concerning their businesses or undertakings. However, the shortcomings in this method is the non-existence of sanctions for non-conformity; this may serve as a setback to the justification for this tactic.

Furthermore, in underpinning the non-existence of transparency in the industry, Oyewunmi and Olujobi in the article "Transparency in Nigeria's Oil and Gas Industry: Is Policy Re-Engineering the Way Out?,” (Oyewunmi and Olujobi, 2016a, 2016b) argued that clandestineness in the modus operandi of grants of oil contracts, permits, leases and other businesses by the NNPC is due to the dearth of severe stipulations in the NNPC Act [12] concerning transparency and record-keeping on oil transactions. It is the researcher's perspective that publication to the public of the financial statements and business contracts made by the NNPC and National Petroleum Investment Management Services will not repudiate commercial agreements' confidentiality clauses in the industry. It is submitted that transparency legislation should incorporate voluntary reporting measures to discourage corruption, but the article is considered failed to the allusion to the implementation problems of anti-corruption laws by the anti-corruption agencies. 
Besides, Eigen, in his article, "Fighting Corruption in a Global Economy: Transparency Initiative in the Oil and Gas Industry," (Eigen, 2007) outlined that the Extractive Industry Transparent Initiative's goal is to enhance transparency by demanding firms to divulge revenues paid to the government in addition to the publication of income receipts by the government from oil firms, with an autonomous auditor authenticating the correctness of the information revealed for the general populace scrutiny of how oil revenues are expended (Olujobi, 2021). He neglected to explain how the dearth of stringent penalties for nonconformity with its stipulations influences the efficiency of the agency.

Though, Section 5 of the Act assigned the duty of selecting the National Stakeholders Working Group members on the President devoid of any legislative endorsement by the National Assembly. This is a fundamental defect of the Act. This necessitates modification to enhance the component of transparency. Furthermore, in his article, "A Critique of the Enforcement of Nigeria Extractive Industries Transparency Initiative (NEITI) Act 2007 in Nigerian Oil and Gas Sector," (Okeke, 2013) Okeke contended that Section 16 of the Act approved the penalty of $\$ 5-30 \mathrm{~m}$ or incarceration for two years as sanctions for oil firms, their managements and government's officials who offer fictitious data or neglect to make available any information when necessary. The punishments seem deficient, bearing in mind the billions of dollars that are engendered from the industry. Two years of incarceration does not have a rigorous dissuasion consequence, seeing the prevalence of corruption in the industry.

Moreover, no petroleum firm has been stated to be reprimanded for non-conformity with the NEITI Act, notwithstanding significant infringements of the Act. The researcher concedes that inadequacy of sanctions under the Act may encourage non-compliance. In the same vein, there is a necessity for the Act to be revised to authorise the NEITI to prosecute offenders. There is a necessity for mutual assistance between investigators and prosecutors for the significant trial of corruption cases and for integrating transparency to the industry. Also, there is a need for severe execution of anti-corruption penalties against corruption offenders.

The fundamental challenge of the agency is that ascertained corruption in the numerous audit reports was not arraigned timely by the anti-corruption agencies, and the paper did not appropriately stress this. There is the necessity for a stringent law that requires the accountability of upstream petroleum industry's cash flows of the NNPC with the purpose of remittance of oil revenues to the Federation Account with obligatory reporting procedures. The penalty of two or more years of incarceration and a fine of up to US $\$ 151,000$ does not hold good discouragement values to fight corruption. Thus, there is a necessity to overhaul the Act.

Concerning the Nigerian Extractive Industries Transparency Initiative Act, the fundamental challenge of the agency is statutory; as it has no legal power to coerce the NNPC to pay outstanding oil revenues to the Federation Account [13]. The Act should be modified to confer on it the authority to arraign erring oil firms and to compel the payment of outstanding oil payments from the NNPC to the Federation Account. There is consequently the necessity to widen the scope of its transparency horizon to the Petroleum Technology Development Fund, NDDC and other oil-producing communities to incorporate transparency in the industry as well as to assist in the performance of its obligations in the industry.

Also, the Public Procurement Act [14] was passed to eradicate corruption in Nigeria's procurement scheme and to embed transparency in the industry. It prevents conflicts of interest and encompasses penalties, for instance, suspension and debarment of firms declared culpable of deception and infringement of contract (GAN Business Anti-corruption 
JMLC 26,7

Portal, 2015). The Act does not apply to the procurement by the national defence or national security, but where the President expressly authorises it (GAN Business Anti-Corruption Portal, 2015). There is a need to exercise restraint concerning these exemptions because that too, can increase corruption. The Act neglects to offer distinct differences on categories of procurement; it contains only two approaches of tendering unique and restricted approaches of procurement and favours only open competitive tendering. Additionally, it fails to provide the mechanisms for dispute resolution.

Further, concerning the Code of Conduct Bureau and Tribunal Act, [15] Chene and Transparency International's article on "Foreign Exchange Controls and Assets Declarations for Politicians and Public Officials" (Chene and Transparency International, 2011) articulated his worry that the bureau has not performed as expected due to the paucity of funds and human resources to scrutinise the entire public service in Nigeria. It was obligatory to check the truthfulness of the affirmations made by government officials in the industry. [16] Idowu (2000), in his article "An Appraisal of the Code of Conduct for Public Officers in Nigeria," emphasised the necessity for integrity to supersede the privacy of any government's executives in the industry. The Code does not apply to the informal sector, where numerous upstream petroleum operators are located.

The punishments for the contravention of the Act are the vacation of office irrespective of being voted or selected, ineligibility from holding any public office, whether by voting or not for a duration not beyond ten years. Forfeiture of any assets obtained through the misuse of office to the government [17]. It is imperative to state that the penalties stipulated by the Act are insufficient. A period of incarceration will have additional discouragement value than a forfeiture or other non-custodial approaches of chastisement.

The proposed PIGB [18] is expected to unbundle the NNPC into sustainable profitmaking petroleum legal entities, but no comprehensive stipulations on fiscal provisions, for instance, host communities, taxes and royalties are not in existence yet. The transformation may be deficient of privatisation, as the possession of these profit-making legal entities is conferred on the government, which infringes Section 18 of the repealed Companies and Allied Matters Act, [19] which prohibits the formation of a company with less than two persons but conforms to Section 18(2) of the newly assented Companies Allied Matters Act, 2020 , but the Act should be modified with severe anti-corruption sections before the Bill is assented by the President.

The Bill (Ighodalo, 2020) has an enormous prospect for combating corruption in the industry. If passed into law and religiously enforced, it is anticipated that it will present a clear separation between policy, regulatory and commercial functions of the NNPC, integrate transparency and good governance along with the sound regulatory framework for Nigeria's petroleum industry.

Also, Sections 2(1), (2) and (3) of the Bill offer the minister's right of pre-emption; this is an amendment in conformity with the existing financial realities and projected future challenges in the industry. Under the proposed Bill, the punishment for non-conformity with its provisions has been snowballed to $\$ 10,000,000.00 \mathrm{~m}$ or incarceration for six months [20]. For impediment, there is a fine of $\$ 5,000,000.00 \mathrm{~m}$ or incarceration for six months [21]. The Minister of Petroleum and Energy Resources is also authorised to make guidelines to upsurge the monetary fines under the Bill, and the unencumbered power to award licences and leases [22]. This can only be implemented now with the approval from the Nigerian Petroleum Regulatory Commission, different from the preceding law (Odujinrin, 2020).

It is the opinion of the researcher that the Bill is an improvement on the existing legal regime in the petroleum industry and on the old Petroleum Industry Bill, whereby the Petroleum Minister and Energy Resources nominated the Chief Executive Officer of the 
Petroleum Inspectorate with the endorsement from the National Council of Ministers, the Department of Petroleum Resources, as well as its Director-General.

The authority to enact regulations is conferred on the Minister, under Section 9 of the Petroleum Act and preserved by the Petroleum Industry Bill has been obliterated. It has been bestowed on the planned Nigerian Petroleum Regulatory Commission, which is to be the regulatory agency for the industry as specified in Section 8(1)(2) of the Bill. The planned equity in the proposed firm should be given to Niger Delta communities, and their state governments to increase the ownership of oil, tackle the challenge of dissatisfaction among the host communities and present an indistinct separation between the regulators and the regulated in the industry. This will end corruption and the long predominant practice of non-payment of oil revenues to the Federation Account.

\section{Petroleum industry governance bill 2017 and the outlook of the upstream industry}

The PIGB 2017 is to regulate the oil sector and to rescind all the existing laws in the industry. The Bill initiates novel clauses and endorses some existing organisations to entrench good governance and accountability in the industry. Under Bill, the Minister of Petroleum Resources is assigned the overall governance, policy and strategy of the industry. He has pre-emptive rights to entirely oil products on the occasion of National tragedy but does not have the power to grant, renew, amend, increase or cancel any lease or permit awarded under the Act and he cannot inaugurate new entities. The National Petroleum Regulatory Commission (NPRC) is to replace the current Department of Petroleum Resources. The body is to govern the industry. It is to be independent of the Minister of Petroleum but to be overseen by a Governing Board selected by the President with the endorsement of the Senate. Some germane problems require to be tackled before the Bill is assented to by the President. There are the Bill requires the establishment of Boards for the proposed commercial legal entities. The arrangement of these Boards may not specify the appropriate balance of controls to ensure efficient Board management to eliminate the risk of executive foist their decisions on members and to entrench the autonomy of the Board to combat unnecessary government interference so; there is the necessity for an increase in the aggregate of non-executive directors to executive directors with comprehensive conditions of service to ensure the independence of the directors. In contrast, the Bill offers detailed tenures of non-executive directors but neglected to make provision for steady tenures for the executive directors to safeguard them from parochial politics. The implementation of specific contracts of the executive directors may combat this problem.

The newly proposed commercial legal entities are to be controlled by the provisions of the new Code of Corporate Governance originated from the Securities and Exchange Commission (SEC). However, the Bill does not contain stringent measures to prevent or combat possible divergences that may arise between its stipulations and those of the SEC code to forestall prospective obscurity by highlighting on the pre-eminence of the Bill over those of the SEC code, where conflicts arise.

The broad powers given to NPRC may be consequently abused; there is the necessity for the appropriate reformation of the Board for efficient implementation of its obligation. The setting of oil product prices through laws for a fair market value of petroleum merchandises and tariffs for gas processing and transportation is a sign that the Federal Government is unenthusiastic about liberalising the downstream sector of the industry entirely. The Bill offers divestment of at least $40 \%$ of the shares in the NPC within ten years of registration but investors may be disinclined to invest in a firm which will be primarily owned and run by the government. Also, this sole ownership by the government conforms to the provisions 
JMLC

26,7

18

of Section 18(2) of the Companies Allied Matters Act 2020 as against the provisions of the repealed Act.

Equally, the creation of a sole regulator for the industry may give colossal authority to the NPRC, which may be misused and caused the ineffectiveness and superfluous bureaucracy. The Bill has the prospective to enhance the oil industry substantially. However, its success rests on the political will of the Federal Government to ensure it is approved and to guarantee that its stipulations are appropriately implemented to boost transparency and accountability in the industry. However, since the Bill is a work in progress, there is a need to harmonies all apprehension and concerns for instance integration of anti-corruption clauses before it is assented to by the President to attain its goal of remodelling the industry for the general good of all citizens.

\section{Discussion of findings or results}

- The study observes that there is a need for comprehensive reform in Nigeria's anticorruption legislation with a mixture of legal and non-legal panaceas to combat corruption. The solution lies in the stringent enforcement of existing anti-corruption and transparency laws and the reform of various defects pinpointed in the laws to embed transparency in the industry. For an efficient soft law approach, there is the need for the current anti-corruption legal framework to be supplemented with the Whistle Blowers Protection Bill, Civil Forfeiture of Proceeds of Corruption Bill and Witness Protection Bill. The non-existence of these specific anti-corruption laws indicates that Nigeria's anti-corruption legal framework is deficient.

- There is a necessity not to depend solely on laws for transparency in the industry.

- A high-tech anti-corruption technique may be indispensable; therefore, there is the need for adoption incorporation of soft and hard laws, to combat corruption in the industry. The method basically depends on civil legislation instead of the conventional criminal justice system for fighting corruption, which is very timeconsuming. The justification for this method is the option for compensations, properties seizure, payments and other pecuniary reliefs. Also, when anti-corruption organisation neglect or refuse to sue for corruption, private populaces can commence civil suits. The standard of proof is a balance of probabilities, which is which can easily be proved than proof beyond reasonable doubt as required under the administration of criminal justice system.

- There are weaknesses in Nigeria's national anti-corruption legal regime. This hampers the efficient execution of anti-corruption laws, and there is non-usage of soft law method to combat corruption in the industry (Figure 2).

Figure 2.

Benefits of stringent anti-corruption legal framework

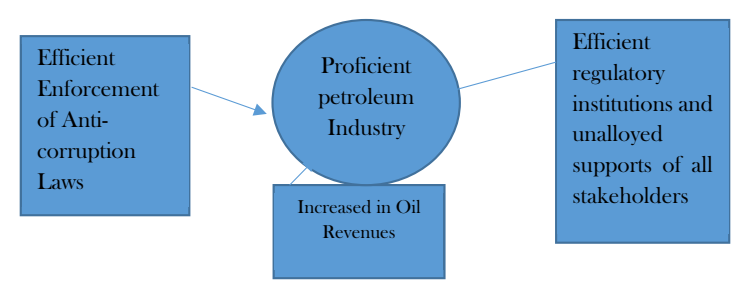

Source: The Author 2020 


\subsection{Highlight of limitations of this study}

Investigations revealed during this study that NNPC's operations are characterised with poor record-keeping, lack of accountability as well as secrecy in the award of oil contracts, oil licence, leases and other financial transactions due to non-disclosure or confidentiality clauses contained in most of these contracts. Also, an arbitration proceeding limit access to their records and some of these agreements under contentions. This has also limited the success of this research work and generalising its findings.

\section{Nigeria's upstream petroleum industry}

\section{Recommendations}

Novel methods that can be used to exterminate corruption such as the enactment and incentivisation of the Whistle-Blowers Protection Act and Civil Forfeiture of Proceeds of Corruption Act as well as the execution of populace sensitisation schemes on the damaging magnitudes of corruption in the industry. The Whistle Blowers Protection Act, which provides fortification to any clandestine informant and inspires citizens to uncover corruption devoid of the apprehension of counter-attack, [23] has not been passed into law by the lawmakers. The Civil Forfeiture of Proceeds of Corruption Act, if legislated upon, will deprived corrupt government's officials the right to possessions accrued via corruption, as practised in Norway, the USA and UK where anti-corruption laws are rigorously implemented.

There is the necessity to modify the NNPC Act, 1977, to spell explicitly what funds the Corporation can maintain and how they can be used as an alternative to the current provision, which is not clear enough. The modification of Section 7 of the Act must indicate how the Corporation should maintain and fund its businesses, its tax arrangement and disbursements of dividends to encourage transparency, instead of the current position that infringes Section 80, 162 of the 1999 Constitution, which necessitates payments of entirely oil revenues into the Federation Account (Sayne and Gillies, 2015). The regulatory functions of the NNPC should be detached from its commercial responsibilities, such as in Norway, where the National Oil Company (Statoil) functions like other commercial oil firms devoid of any special status.

Anti-corruption legislation, however well designed, will be elucidated by the court of law, and this has often led to the emergence of difficulties where laws are not appropriately interpreted. Consequently, the judiciary needs to be strengthened to eliminate the protracted prosecutions of corruption cases and the alleged corruption at the Nigerian bench.

The government has lost not less than 150,000 barrels of crude oil estimated at $\$ 6 \mathrm{bn}$ yearly to crude oil theft, (Any, 2015) Moreover, this has diminished the national revenue, which ought to have accumulated to the Federation Account. This is a result of the unproven collusion of the Federal Government's officials in the industry. The non-existence of detailed legislation on oil and gas that proscribes crude oil theft is the reason for this offence. Section 3(e), (f), (iv) of the Nigeria Security and Civil Defence Corps Act [24] only provides for pipeline protection as one of the tasks of the Corps, devoid of defining clearly the punishments to be meted out to the perpetrators. There is the need for detailed sections in the PIGB, proscribing crude oil theft and other corruption-related undertakings in the industry.

The use of crude oil-tracking scheme to monitor production and movements of crude oil in Nigeria via contemporary technologies with DNA fingerprinting on crude oil barrels to assign a status of legitimacy to crude oil gotten and vended by the NNPC may be essential to fight oil theft and enhance transparency in the industry. If these technologies are appropriately systematised, it can be a veritable anti-corruption instrument to distinguish 
JMLC 26,7

stolen crude oil from the country. Due diligence in the undertakings or activities of the refineries, this is also one anti-corruption instrument for fighting oil theft and corruption in the designated case study nations.

Nigeria should imitate this in our anti-corruption laws. Oil firms functioning in the industry should implement comprehensive assessment of their processes (United Nation Global Compact, 2013) Moreover, corruption exposures (Navigant Consulting Inc., 2010) All-inclusive due diligence like Norway, where petroleum firms are obliged to inaugurate whistle-blower hotlines for employees and independent contractors who desire to alert the firm or anti-corruption organisations of corruption through mobile phones, nameless email addresses or by using outdoor whistle-blowing hotlines under the supervision of an autonomous service provider to report corrupt undertakings or contracts. Debarment of oil firms' directors, exclusion of firms guilty of corruption from participating in public procurement/tenders and non-prosecution and deferred prosecution agreements are also among the modules Nigeria can absorb from the designated case study nations.

\section{Conclusions}

The research underlining the necessity to enhance the current anti-corruption legislation to embed transparency, accountability and efficiency in the industry and finalise that anticorruption agencies in Nigeria are impractical because of the absence of political will of the Federal Governments to combat corruption with adequate or satisfactory budgets and the stringent enforcement of anti-corruption laws. The Federal Government has tried to alleviate the effects of corruption and enhance durable infrastructure in the country by enacting a plethora of anti-corruption legislation proscribing corruption, but these seem lacking due to the feeble execution.

This study recommends the usage of procurement disentitlement system as an instrument to discourage corruption and to enhance veracity in the public procurement system. It impedes firms and individuals from partaking in government's contracts for a specified duration if established guilty of corruption or contravention of contract. It was uncovered that an analogous provision under Section 58(1)(6)(a) of the Nigerian Public Procurement Act offers for debarment or blacklisting, but this provision is inelegant implemented to fight corruption in the industry unlike in other jurisdictions where they are executed stringently.

This study revealed that the inputs of oil-producing communities in the grant or licencing procedure would give them a consciousness of ownership. The effect of petroleum firms' undertakings on oil churning out communities should be a fundamental prerequisite for consideration before the grant of petroleum permits or contracts in the industry while participatory ownership is still non-existent under the Nigerian legal framework. The inputs of oil-producing areas in the award process of oil blocks or licences in the industry by regulatory organisations will offer them a sense of belonging and may decrease the constant tensions for resource management by the oil-producing areas, pipeline vandalisation to zero levels and minimise corruption too. This study also recommended regulatory instruments that can eliminate corruption, for instance, the enactment and incentivisation of conformity with the Whistle-blowers Protection Act and the Civil Forfeiture of Proceeds of Corruption Act in addition to populace sensitisation on the damaging effects of corruption on the country with the necessity to encourage transparency and accountability in the petroleum industry and the country as a whole. 


\section{Notes}

1. Black's Law Dictionary Eighth Edition 2004 defines Force majeure as a clause that permits oil firms to halt operations or shipments without any infringement on the contracts.

2. Cap. C15, Laws of the Federation of Nigeria, 2004.

3. Nigeria Extractive Industries Transparency Initiative (NEITI) Act, 2007.

4. Nigeria Sovereign Investment Authority (Establishment) Act 2011, Cap N.166, Laws of the Federation of Nigeria 2004.

5. Niger-Delta Development Commission (Establishment) Act, 2000 Act, No. 6, Laws of the Federation of Nigeria.

6. Recovery of Public Property (Special Provisions), Act Cap R. 4, Laws of the Federation of Nigeria, 2004.

7. Bello Akeem Olajide, "Redefining the Mental Element of Bribery in Nigeria" (Unpublished $\mathrm{PhD}$ Thesis, Faculty of Law, Department of Public Law, University of Lagos, Nigeria), p. 3.

8. (NNPC) Act, Cap N123, LFN, 2004.

9. 1969 (as amended).

10. United Nations Convention against Corruption General Assembly Resolution 58/4 of 31 October 2003.

11. Article 51, United Nations Convention against Corruption, 2003.

12. 1969 (as amended).

13. Nigerian Extractive Industries Transparency Initiative 2014 Annual Activity Report.

14. Laws of the Federation of Nigeria (LFN), 2004.

15. Laws of the Federation of Nigeria (LFN), Cap. C. 15, 2004.

16. Ibid, Schedule 5, s. 11 (1-3).

17. Ibid, ss.20-22 (1) (2), Cap. C. 15 Laws of the Federation of Nigeria, 2004.

18. 2015.

19. 2004.

20. S. 3(3) Petroleum Industry Governance and Institutional Framework Bill, 2017.

21. Ibid, s.3(4).

22. Petroleum (Drilling and Production) Regulations No: 9, 2006 and applications are to be made to the Minister for licence and lease applications would now be required to be made to Nigerian Petroleum Regulatory Commission.

23. Article 9, Council of Europe Convention against Corruption.

24. No.6, 2007, (Amendment Act).

\section{References}

Abdullahi, U. and Madu, I. (2015), "Evidence of petroleum resources on Nigerian economic development 2000-2009", Business and Economics Journal, Vol. 6 No. 2, p. 1.

Adebisi, M.A. (2015), "The political economy of oil price deregulation and the subsidy fraud crisis: a study of systematic bureaucratic corruption in Nigeria", Journal of Energy Technologies and Policy, Vol. 5 No. 9, p. 36. 
JMLC 26,7

Ajuzie, G.C. (2010), "Bureaucratic corruption in public administration: Its effects on the Nigerian economy", p. 130, available at: http://globalacademicgroup.com/journals/academic\% $\% 20$ scho larship/bureaucratic\% 20corruption\%20in\%20public.pdf (accessed 5 August 2020).

Akinola, A.O. (2015), "Globalisation, sustainable democracy and deregulation in Nigeria: a case study of the downstream oil sector", Unpublished PhD Thesis, University of KwaZulu-Natal, p. 143.

Amundsen, L. (1999), "Political corruption: an introduction to the issues", p. 5, available at: www.cmi. no/publications/file/1040-political-corruption.pdf (accessed 17 August 2020).

Amundsen, I. (2020), Political Corruption: An Introduction to the Issues, Chr. Michelsen Institute Development Studies and Human Rights, p. 7, available at: www.cmi.no/publications/file/1040political-corruption.pdf (accessed 17 August 2020).

Anechiarico, F. and Jacobs, J. (1996), The Pursuit of Absolute Integrity, University of Chicago Press, Chicago, p. 20.

Anele, K. (2015), "Multinationals are notorious for tax evasion. Do you agree?", p. 1, http:// documentslide.com/documents/multinationals-are-notorious-for-tax-evasion2.html (accessed 1 March 2020).

Any, S.F. (2015), "Illegal oil bunkering and oil theft in Nigeria: Impact on the national economy and the way forward”, Illini Journal of Arts and Social Sciences, Vol. 1 No. 1, p. 53.

Ayado, S. (2020), "Again, senate insists on probe of N40bn in NDDC", Business Day Newspaper available at: https://businessday.ng/news/article/again-senate-insists-on-probe-of-n40bn-innddc/ (accessed 1 July 2020).

Ayoade, M.A. (2011), "Nigerian national petroleum corporation and prospects for transparency in the petroleum industry bill", Knust Law Journal, No. 5, p. 89.

Barbara, C.G. and Kathleen, A.L. (2006), "Investigation of Halliburton Co./TSKJ's Nigerian business practices: Model for analysis of the current anti-Corruption environment on foreign corrupt practices act enforcement", Journal of Criminal Law and Criminology, Vol. 96 No. 2, p. 505.

Bello, A.T. (2017), "Oil and gas problems in Nigeria: the impending problems and the preferable solutions", p. 2, available at: SSRN:https://ssrn.com/abstract=3072236 or 10.2139/ssrn.3072236 (accessed 11 April 2020).

Carlyle, R. (2020), "Why does the United States do not have a national oil company?", available at: www.quora.com/why-does-the-us-does-not-have-a-national-oil-company (accessed August 2 2020).

Carvalho, R. (2017), “SPTEC advisory - 2016 country review”, p. 60, available at: www.sptec-advisory. com/sptec_advisory-nigeria_2016_news_review.pdf (accessed 2 August, 2020).

Central Bank of Nigeria (2019), "Daily crude oil price”, available at: www.cbn.gov.ng/rates/dailycrude. asp (accessed August 16 2020).

Chene and Transparency International (2011), "Foreign exchange controls and assets declarations for politicians and public officials", available at: www.u4.no/publications/foreign-exchangecontrols-and-assets-declarations-for-politic (accessed 18 August 2020).

Davis, K.E. (2020), "Does the globalisation of anti-Corruption law help developing countries?”, (2009), available at: https://nyudri.files.wordpress.com/2011/10/driwp61.pdf (accessed 17 August 2020).

Eigen, P. (2007), "Fighting corruption in a global economy: Transparency initiative in the oil and gas industry", Houston Journal of International Law, Vol. 29 No. 2, p. 327.

GAN Business Anti-corruption Portal (2015), 'USA Corruption Report' available at: www.business-anticorruption.com/country-profiles/usa (accessed 17 August 2020).

Global Witness (2017), "Landmark prosecution as Nigerian authorities charge shell and eni over shady $\$ 1.1$ billion OPL 245 deal”, available at: www.globalwitness.org/en/press-releases/landmarkprosecution-Nigerian-authorities-charge-shell-and-eni-over-shady-11-billion-opl-245-deal/ (accessed 2 August 2020). 
Guzman, A.T. (2020), “A compliance based theory of international law”, available at: www.law. berkeley.edu/files/guzmanComplianceandIL.doc (accessed 17 August 2020).

Henderson, D.R. (2020), "Rent-Seeking”, p. 1, available at: www.econlib.org/library/enc/rentseeking. html (accessed 4 August 2020).

Idowu, A.A. (2000), "An appraisal of the code of conduct for public officers in Nigeria", Philippine Journal of Public Administration, Vol. 44 Nos 1/2, p. 100.

Igbinedion, S. (2011), "Culpability of attorney general of the federation in multinational companies' corporate liability", The Guardian available at: www.guardiannewsngr.com/index.php?option= com_content\&view=article\&id=58689:culpability-of-agf-in-multinational-companies-corporateliability\&catid=42:law\&itemid=600 (accessed August 142020$)$.

Ighodalo, W. (2020), "Review of the petroleum industry governance and institutional framework bill", available at: www.banwo-ighodalo.com/assets/resources/16f9efca630ad479ab019af7b736e809. pdf (accessed 17 August 2020).

Iyanda, D.O. (2012), "Corruption: Definition, Theories and concepts", Arabian Journal of Business and Management Review, Vol. 2 No. 4, p. 40.

Krueger, A.O. (1974), "The political economy of the Rent-Seeking society", American Economic Review, Vol. 64 No. 3, p. 291.

Lucinda, A.L. (2020), "The united nations convention against corruption: the globalization of anticorruption standards", Conference of the International Bar Association International Chamber of Commerce Organization for Economic Cooperation and Development, available at: www.steptoe. com/assets/attachments/2599.pdf (accessed 17 August 2020).

Moghalu, K. (2018), "Obsolete legislation and the challenges of national development: Nigeria's petroleum industry experience", available at: www.financialnigeria.com/obsolete-legislationand-the-challenges-of-national-development-nigeria-s-petroleum-industry-experience-interview-98. html (accessed 5 August 2020).

Mushtaq, H.K. (2000), Rent-Seeking as Process, Cambridge University Press, New York, NY, p. 5, available at: https://core.ac.uk/download/files/103/2792081pdf (accessed 14 August 2020).

Navigant Consulting Inc (2010), "The United Kingdom bribery act 2010: What does it mean for multinationals", available at: www.navigantconsulting.com (accessed 18 August 2020).

Nigeria Extractive Industries Transparency Initiative (NEITI) (2013), "Financial, physical and process audit: an independent report assessing and reconciling physical and financial flow within Nigeria's oil and gas industry”, p. 86, available at: www.proshareng.com/admin/upload/reports/ 2013oilgasreport.pdf (accessed 13 August 2020).

Nigeria Extractive Industries Transparency Initiative (NEITI) (2016), 'NEITI 2016 Annual Progress Report', p. 37, available at: www.neiti.gov.ng/index.php/resources/internal-resources/workplansreports/annual-neiti-eiti-reports (accessed 2 August 2020).

Nigeria Extractive Industries Transparency Initiative Policy Brief (2017), "Unremitted funds, economic recovery, and oil sector reform”, 3, available at: www.neiti.gov.ng/phocadownload/neiti-pb3280317.pdf (accessed 2 August 2020).

Nigeria Extractive Industries Transparency Initiative (2014), Nigeria Extractive Industries Transparency Initiative Oil and Gas Report 2014, available at: http://cislacnigeria.net/wp-content/uploads/2017/ 01/neiti-oilgas-report-2014-exec-summary-301216pdf (accessed 10 August 2020).

Nigeria Extractive Industry Transparency Initiative (2014), "Nigeria: Recovering missing payments", NEITI Progress Report, available at: http://progrep.eiti.org/2014/country-focus/nigeria (accessed 10 August 2020).

Nigerian National Petroleum Corporation (NNPC) (2020) "Crude oil price", available at: www. nnpcgroup.com/pages/oil-prices.aspx (accessed 6 April 2020).

Nliam, O. ' (2015), "Assessing the adequacy of international and regional legal framework against corruption in the public sector' ", in Ayoade, M.A. and Igbinedion, S.A., (Eds) Legal Perspectives 
JMLC 26,7 to Corruption, Money Laundering and Assets Recovery in Nigeria, Department of Jurisprudence and International Law, Faculty of Law, University of Lagos, Lagos, p. 29.

Nwanolue, B.O.G. and Osegbue, C. (2013), "The Nigerian state and crude oil bunkering in Niger Delta: Examining the environmental vulnerability", Journal of Social Sciences, Vol. 3 No. 1, p. 37.

Nwokeji, G.U. (2007), "The Nigerian national petroleum corporation and the development of the Nigerian oil and gas industry: History, strategies and current directions", p. 49, available at: www.bakerinstitute.org/media/files/page/9b067dc6/noc_nnpc_ugo.pdf (accessed 2 August 2020).

Odujinrin, A. (2020), "Discretionary powers of minister of petroleum: an analysis of the petroleum industry governance bill 2016 - powers of the minister", available at: www.petro leumindustrybill.com/tag/discretionary-powers-minister-of-petroleum/\#.wfubdy9sxdg (accessed 17 August 2020).

Ogbonna-Nwaogu, I. (2010), "Contradictory positions of government and its anti-Graft agencies: an analysis of the halliburton case from media reports", Journal of Alternative Perspectives in the Social Sciences, Vol. 2 No. 2, p. 663.

Okeke, V.O.S. (2013), "A critique of the enforcement of Nigeria extractive industries transparency initiative (NEITI) act 2007 in Nigerian oil and gas sector", British Journal of Arts and Social Sciences, Vol. 14, p. 107

Okojie, P. and Momoh, A. (2005), "Corruption and the crisis of development in Nigeria", Paper Presented at the Conference on 'Redesigning the State?, Political Corruption in Development Policy and Practice' held at Manchester Metropolitan University, p. 3.

Olisah, C. (2020), "United Kingdom court dismisses \$1.1billion Nigerian corruption lawsuit against shell, eni”, available at: https://nairametrics.com/2020/05/23/uk-court-dismisses-1-1billionNigerian-corruption-lawsuit-against-shell-eni/ (accessed 2 August 2020).

Olujobi, O.J. (2020), "Analysis of the legal framework governing gas flaring in Nigeria's upstream petroleum sector and the need for overhauling", MDPI Social Science, Vol. 2020, p. 9132.

Olujobi, O.J. (2021), "Combating insolvency and business recovery problems in the oil industry: proposal for improvement in Nigeria's insolvency and bankruptcy legal framework, Heliyon", No. 7, p. e06123,1-11.

Olujobi, O.J. and Olujobi, O.M. (2020), "Theories of corruption 'public Choice-Extractive theory' as alternative for combating corruption", International Journal of Environmental Sustainability and Green Technologies, Vol. 11 No. 2, p. 8.

Olujobi, O.J., Olujobi, O.M. and Ufua, D.E. (2020), "A critical appraisal of legal framework on deregulation of the downstream sector of the Nigerian petroleum industry", International Journal of Management, Vol. 11 No. 6, pp. 252-268.

Omorogbe, Y. (1996), "Law and investor protection in the Nigerian natural gas industry", Journal of Energy and Natural Resources Law, Vol. 14 No. 2, p. 179.

Onya, R.M. and Elemanya, A.V. (2016), "Analysis of president Buhari's anti-Corruption policy: a reality or an illusion?", International Journal of Advanced Academic Research Social and Management Sciences, Vol. 2 No. 11, p. 82.

Organisation for Economic Cooperation and Development (OECD) (2011), "G20 anti-Corruption action plan - protection of whistleblowers", Study on Whistleblower Protection Frameworks, Compendium of Best Practices and Guiding Principles for Legislation, available at: www.oecd. org/g20/topics/anti-corruption/48972967.pdf (accessed 17 August 2020).

Organisation of the Petroleum Exporting Countries (2020), "OPEC daily basket price stood at $\$ 45.08$ a barrel Wednesday, august 12 2020", available at: www.\$45.08abarre (accessed 14 August 2020).

Otusanya, O.J. (2011a), "The role of professionals in anti-Social financial practices: the case of Nigeria", Journal Accountancy Business and the Public Interest, p. 80, available at: http://visar.csustan.edu/ aaba/otusanya2011.pdf (accessed 6 August 2020). 
Otusanya, O.J. (2011b), "The role of multinational companies in tax evasion and tax avoidance: the case of Nigeria", Critical Perspectives on Accounting, Vol. 22 No. 3, p. 317.

Oyewunmi, O.A. and Olujobi, O.J. (2016a), "Transparency in Nigeria's oil and gas industry: is policy Re-Engineering the way out?", International Journal of Energy Economics and Policy, Vol. 7 No. 3, p. 630.

Oyewunmi, O.A. and Olujobi, O.J. (2016b), “Transparency in Nigeria's oil and gas industry: is policy ReEngineering the way out?", International Journal of Energy Economics and Policy, Vol. 5 No. 4, pp. 630-636.

Padideh, A. (2020), "Controlling corruption in international business: the international legal framework", UNODC Organisation, available at: www.eolss.net/sample-chapters/c13/e6-67-0307.pdf or www.unodc.org/documents/treaties/organized_crime/cop6/ctoc_cop_2012_crp/ct oc_cop_2012_crp4.pdf. (accessed 16 March 2020).

Reuters, T. (2004), "Corruption costs Nigeria $40 \%$ of oil wealth, official says 100, 000 barrels said to be stolen each day", available at: www.boston.com/new/world/africa/articles/2004/12/17corruption.

Ribadu, M.N. (2012), "Report of the petroleum revenue special task force", p. 107, available at: www. premiumtimesng.com/docs_download/report_of_the_ribadu_led_petroleum $\% 20$ revenue $\% 20 \mathrm{sp}$ ecial $\% 20$ task $\% 20$ force $\%$ 202012.pdf (accessed 3 August 2020).

Sayne, A. and Gillies, A. (2015), "Inside NNPC oil sales: a case for reform in Nigeria", available at: https://resourcegovernance.org/sites/default/files/nrgi_insidennpcoilsales_completereport.pdf (accessed 19 August 2020).

Smith, J. and Pieth, M. (2007), "The recovery of stolen assets: a fundamental principle of the united nation convention against corruption”, 2 U4 Brief 1, p. 4, available at: www.u4.no/publications/ the-recovery-of-stolen-assets-a-fundamental-principle-of-the-un-convention-against-corruption/ (accessed 12 August 2020).

Take, N. (2014), “The State-Backed oil company in Nigeria's petroleum economy: Evolution, dilemmas and paradoxes", International Journal of Development and Sustainability, in Global Witness, the Scramble for Africa Oil, Gas and Minerals, Vol. 3 No. 3, pp. 2 available at: www.globalwitness. org $/$. . ./rigged $\% 20$ the $\% 20$ scramble $\% 20$ for $\% 20$ africa's $\%$ (accessed 2 August 2020).

United Nation Global Compact (2013), "A guide for anti-Corruption risk assessment", available at: www.spainsif.es/sites/default/files/upload/publicaciones/riskassessmentguide.pdf (accessed 18 August 2020).

World Bank (2017), World Development Report 2017: Governance and the Law, p. 5, www.worldbank. org/en/publication/wdr2017 (accessed 2 August 2020).

\section{Further reading}

Akinrele, A. (2016), "The current impact of global crude oil prices on Nigeria - an overview of the Nigerian petroleum and energy sector", The Journal of World Energy Law and Business, Vol. 9 No. 5, p. 313.

Alphonsus, O.I. (2015), "Socio-Economic impact of Niger Delta development commission (NDDC) infrastructural projects in selected communities in Imo state Nigeria", Asian Journal of Humanities and Social Science, p. 109.

Arnone, M. and Berlin, L.S. (2014), Corruption: Economic Analysis and International Law, Edward Elgar Publishing, Cheltenham, p. 630.

Ayoade, M.A. (2012), "Evaluating the legal architecture on corruption in Nigeria”, The Nigerian Journal of Contemporary Law, Vol. 18 No. 1, p. 51.

Azmawaty, S.N. and Zakaria, M. (2015), "Breaking the silence: the efficacy of whistleblowing in improving transparency", Scientific Research Journal, Vol. 3, p. 35

Becker, G.S. (1983), “A theory of competition among pressure groups for political influence”, The Quarterly Journal of Economics, Vol. 98 No. 3, p. 371. 
JMLC 26,7

Brunelle-Quraishi, O. (2011), "Assessing the relevancy and efficacy of the United nations convention against corruption: a comparative analysis", Notre Dame Journal of International and Comparative Law, Vol. 2 No. 1, p. 23.

Christiano, T. (2004), "Is normative rational choice theory self defeating?", Ethics an Ethics, Vol. 115 No. 1, p. 14.

Graaf, G.D. (2007), "Causes of corruption: towards a contextual theory of corruption", Public Administration Quarterly, Vol. 31 Nos 1/2, p. 47.

Igbinedion, S.A. (2013), "Enthroning good governance in Nigeria: the challenge of corruption", Justice Journal, Vol. 1 No. 1, p. 166.

Ikpeze, N. (2013), "Fusion of anti-Corruption agencies in Nigeria: a critical appraisal", Afe Babalola University, Journal of Sustainable Development Law and Policy, No. 5, p. 148.

Jacob, O.A. (2010), "Procurement law in Nigeria: Challenge for attainment of its objectives", University of Botswana Law Journal, Vol. 4 No. 1, p. 131.

Langseth, P. (1999), "Prevention: an effective tool to reduce corruption, global programme against corruption", Centre for International Crime Prevention, Office of Drug Control and Crime Prevention, United Nations Office (Paper Presented at the ISPAC Conference on Responding to the Challenge of Corruption, Milan, 19 November 1999), p. 22, available at: www.unodc.org/pdf/ crime/gpacpublications/cicp2.pdf (accessed 17 August 2020).

Low, L.A. and Davis, J.E. (1998), "Coping with the foreign corrupt practices act: a primer for energy and natural resource sectors", Journal of Energy and Natural Resources Law, Vol. 16 No. 3, p. 286.

Nwete, B. (2007), "Corporate social responsibility and transparency in the development of energy and mining projects in emerging markets: is soft law the answer", German Law Journal, Vol. 8 No. 4, p. 315 .

Ocheje, P. (2001), "Law and social change: a Social - Legal analysis of Nigeria's corrupt practices and other related offences act 2000", Journal of African Law, Vol. 45 No. 2, p. 177.

Odularu, G.O. (2007), Crude Oil and the Nigerian Economic Performance, Oil and Gas Business, p. 1, available at: www.ogbus.ru/eng/authors/odularo/odularo_1.pdf (accessed 14 March 2020).

Ogbu, O.N. (2008), "Combating corruption in Nigeria: a critical appraisal of the law Institutions, and the political will", Annual Survey of International and Comparative Law, Vol. 14 No. 1, p. 1.

Oke, Y. (2015), "Strategies for combating money laundering in Nigeria", in Ayoade, M.A. and Igbinedion, S.A.,(Eds), Legal Perspectives to Corruption, Money Laundering and Assets Recovery in Nigeria, Department of Jurisprudence and International Law, Faculty of Law, University of Lagos, Lagos, p. 222.

Okechukwu, E.I. and Inya, C.O. (2011), "The role of EFCC in combating political corruption", Arabian Journal of Business and Management Review, Vol. 1 No. 3, p. 48.

Okpanachi, I.E. and Nathan, A. (2012), "Preventing the oil "resource curse in Ghana: Lessons from Nigeria", The Journal of New Paradigm Research, Vol. 68 No. 6, p. 430.

Olujobi, O.J. and Olusola-Olujobi, T. (2019a), "The appraisal of legal framework regulating gas flaring in Nigeria's upstream petroleum sector: How efficient?”, International Journal of Advanced Research in Engineering and Technology, Vol. 10 No. 3, pp. 234-250.

Olujobi, O.J. and Olusola-Olujobi, T. (2019b), "Insolvency law and business recovery practices in Nigeria's upstream petroleum sector: the need for a paradigm shift", International Journal of Mechanical Engineering and Technology, Vol. 10 No. 1, pp. 1609-1628.

Olujobi, O.J. and Olujobi, O.M. (2020), “Theories of corruption 'public Choice-Extractive theory' as alternative for combating corruption", International, Journal of Environmental Sustainability and Green Technologies, Vol. 11 No. 2, available at: www.igi-global.com/submission/proofing/ document/?did=49496 (accessed 18 August 2020).

Olujobi, O.J. and Oyeunmi, O.A. (2018a), "Oil spillage in Nigeria's upstream petroleum sector: beyond the legal framework”, International Journal of Energy Economics and Policy, Vol. 8 No. 1, pp. 220-226. 
Olujobi, O.J. (2017), "Legal framework for combating corruption in Nigeria: the upstream petroleum sector corruption in perspective", Journal of Advanced Research in Law and Economics, Vol. 3 No. 25, pp. 956-997.

Olujobi, O.J. and Olusola-Olujobi, O.T. (2020), "Comparative appraisals of legal and institutional frameworks governing gas flaring in Nigeria's upstream petroleum sector: How satisfactory?”, Environmental Quality Management, pp. 1-14.

Olujobi, O.J. and Oyewunmi, O.A. (2018b), "Commercial dispute resolution: Has arbitration transformed Nigeria's legal landscape?”, Journal of Advanced Research in Law and Economics, Vol. 9 No. 1, pp. 204-209.

Olujobi, O.J. and Oyewunmi, O.A. (2017), "Annulment of oil licences in Nigeria's upstream petroleum sector: a legal critique of the costs and benefits", International Journal of Energy Economics and Policy, Vol. 7 No. 3, pp. 364-369.

Rose-Ackerman, S. (2002), "Corruption and the criminal law”, Forum on Crime and Society, Vol. 2 No. 1, pp. 1-20.

Sadiq, O.A.I. (2015), "Examining the nexus of corruptio", ARC Journal of Business and Economics, No. 1, pp. 25. "Economic growth and poverty in the democratic governance of Nigeria",

Shabani, B. (2014), "Corruption and the European criminal policy", Academic Journal of Interdisciplinary Studies, Vol. 3 No. 3, p. 255.

Ufua, D.E., Olujobi, O.J., Ogbari, M., Dada, J. and Edafe, O. (2020), "Operations of small and medium enterprises and the legal system in Nigeria, humanities and social sciences communications (", Humanities and Social Sciences Communications, Vol. 7 No. 1.

Ugolini, N.N. (2015), "Pyramidal public corruption: Public policy and bad governance-Nigerian perspective", American Journal of Economics, Finance and Management, Vol. 1 No. 5, p. 408.

US Energy Information Administration (2015), "Nigeria overview", p. 7, available at: www. connaissancedesenergies.org/sites/default/files/pdf-pt-vue/nigeria.pdf (accessed 28 March 2020).

\begin{abstract}
About the author
Dr Olusola Joshua Olujobi his LLB Degree from the prestigious University of Ado-Ekiti in the year 2005 and B.L from the Nigerian Law School, and he was subsequently called to the Nigerian Bar in 2007 as a Solicitor and Advocate of the Supreme Court of Nigeria. He had his Master's Degree in Laws (LLM) at the prominent University of Lagos in 2012 and his Doctor of Philosophy (PhD) Degree in Jurisprudence and International Law in the Faculty of Law, University of Lagos. He was appointed as a Notary Public of the Federal Republic of Nigeria in 2014. He is a lecturer in the Department of Business Management, Covenant University and he is the principal partner in Olujobi Olusola \& Co., Lagos. His experience is multi-disciplinary and spans the legal, regulatory, commercial and contractual arena. His expertise covers the fields of oil and gas, electricity, arbitration and international trade and laws. He is particularly passionate about international law, petroleum law, policy and governance in Nigeria and Africa. Dr Olusola Joshua Olujobi can be contacted at: emails and Mobile No: +238038006033, olusola.olujobi@covenantuniversity.edu.ng, joshuadlaw@yahoo.co. uk
\end{abstract}

For instructions on how to order reprints of this article, please visit our website:

www.emeraldgrouppublishing.com/licensing/reprints.htm

Or contact us for further details: permissions@emeraldinsight.com 